response curves for climacteric symptoms, gonadotrophin release from the pituitary, and bone resorption are all congruent. This equivalence adds weight to our previous studies which suggested that the action of oestrogen on bone is a direct receptor mediated response similar to that underlying the reduction in follicle stimulating hormone and not an indirect action via altered concentration of the calcitropic hormones, which might be expected to produce different dose response characteristics. ${ }^{910}$

It is clear from these results that there is little to be gained from using doses of oestrogen above that which gives an effect equivalent to that produced by a plasma oestradiol concentration of $150 \mathrm{pmol} / 1$ $(41 \mathrm{pg} / \mathrm{ml})$. Indeed, any substantial increase in dose above this level is likely to increase adverse reactions without clinical benefit. Among these is the excessive suppression of bone remodelling, ${ }^{11}$ which is probably essential for the maintenance of healthy bone.

We are grateful to Dr C Chapman for the measurement of plasma follicle stimulating hormone and Dr R E Oakey for the measurement of plasma oestradiol.

\section{References}

1 Geola FL, Frumar AM, Tataryn IV, et al. Biological effects of various doses of conjugated equine estrogens in postmenopausal women. $f$ Clin Endocrinol Metab 1980;51:620-5.

2 Jones MM, Pearlman B, Marshall DH, Grilly RG, Nordin BEC. Dose-dependent response of FSH, flushes and urinary calcium to oestrogen. Maturitas 1982;4:285-90.

3 Tjellesen L, Christiansen C, Hummer L, Larsen N. Unchanged biochemical indices of bone turnover despite fluctuations in 1,25 dihydroxyvitamin $\mathrm{D}$ during the menstrual cycle. Acta Endocrinol (Copenh) 1983;102:476-80.

4 Mack TM, Pike CM, Hedeson BE, et al. Estrogens and endometrial cancer in a retirement community. N Engl f Med 1976;294:1262-7.

5 Towobola OA, Crilly RG, Oakey RE. Oestrone sulphate in plasma from postmenopausal women and the effects of oestrogen and androgen therapy. Clin Endocrinol (Oxf) 1980;13:461-71.

6 Anderson DC. Sex hormone binding globulin. Clin Endocrinol (Oxf) 1974;3:69-96.

Laufer LR, DeFazio JL, Lu JKH, et al. Estrogen replacement therapy by transdermal estradiol administration. Am f Obstet Gynecol 1983;146:533-40.

8 Hodgkinson A, Thompson T. Measurement of the fasting urinary hydroxyproline:creatinine ratio in normal adults and its variation with age and sex. $\mathcal{F}$ Clin Pathol 1982;35:807-11.

9 Selby PL, Peacock M, Barkworth SA, Brown WB, Taylor GA. Early effects of ethinyloestradiol and norethisterone treatment in postmenopausal women on bone resorption and calcium regulating hormones. Clin Sci 1985;69:265-71.

10 Selby PL, Peacock M. Ethinyl estradiol and norethindrone in the treatment of primary hyperparathyroidism in postmenopausal women. $N$ Engl f Med 1986;314:1481-5.

11 Nordin BEC, Marshall DH, Francis RM, Crilly RG. The effects of sex steroid and corticosteroid hormones on bone. I Steroid Biochem 1981;15:171-4.

(Accepted 4 September 1986)

\title{
Hepatocellular carcinoma in urban born blacks: frequency and relation to hepatitis $B$ virus infection
}

\author{
M C KEW, C KASSIANIDES, J HODKINSON, A COPPIN, A C PATERSON
}

\begin{abstract}
Chronic hepatitis B virus infection is far less common in urban born than in rural born southern African blacks, who also have a high incidence of hepatocellular carcinoma. A case-control study was carried out to determine the relative frequency of hepatocellular carcinoma and its relation to hepatitis $B$ virus infection in urban born blacks. Three hundred and ninety two black patients with hepatocellular carcinoma and matched controls seen at two city hospitals were classified by questioning as urban born or rural born. The ratio of rural born to urban born blacks among the controls was $1 \cdot 1: 1.0(207 / 185)$, whereas in the patients with cancer the ratio was 4.8:1.0 (324/68) $(\mathrm{p}<0.0001)$. Analysis of the prevalence of hepatitis $B$ markers in 62 urban born and matched rural born blacks with hepatocellular carcinoma showed no differences in the frequency of current or past hepatitis B virus infection.
\end{abstract}

It is concluded that urban born blacks are less likely than rural born blacks to develop hepatocellular carcinoma, but when they

\footnotetext{
Department of Medicine, University of Witwatersrand Medical School and Johannesburg and Baragwanath Hospitals, Johannesburg, South Africa M C KEW, MD, FRCP, professor and senior physician

C KASSIANIDES, MB, FCPSA, physician

J HODKINSON, MB, FCPSA, senior physician

Institute for Virology, Johannesburg, South Africa

A COPPIN, DMT(VIROL), technologist

South African Institute for Medical Research, Johannesburg, South Africa A C PATERSON, MB, PHD, pathologist

Correspondence to: Professor Kew
}

do the tumour is equally likely to be related to infection with hepatitis $B$ virus. The findings lend further support to an important role for chronic hepatitis B virus infection in the aetiology of hepatocellular carcinoma.

\section{Introduction}

Both chronic hepatitis B virus infection ${ }^{1-3}$ and hepatocellular carcinoma ${ }^{45}$ are common in blacks born in rural areas of southern Africa. Rates of carriage of hepatitis B virus of up to $20 \%$ have been recorded in rural blacks. ${ }^{1-3}$ The infection is almost always acquired in early childhood, predominantly as a result of horizontal transmission. ${ }^{23}$ Rural blacks develop hepatocellular carcinoma while relatively young ${ }^{67}$ and have age standardised frequency rates which may be as high as 104/100000 yearly. ${ }^{45}$ Almost all of these patients show serological markers of current or past hepatitis B virus infection. ${ }^{8}$ Nothing is yet known about either the incidence of hepatocellular carcinoma or its relation to chronic hepatitis B virus infection in blacks who are born and grow up in an urban environment. We, however, have recently shown that urban black children have a carriage rate of hepatitis B virus of only $1 \% .{ }^{9}$ If chronic infection with this virus is proved to be a main cause of hepatocellular carcinoma-and published evidence is persuasive ${ }^{10} 11$ - then the incidence of this tumour in blacks born in urban areas should be appreciably lower than that in blacks born and growing up in rural areas. We have therefore carried out a case-control study to determine the frequency of hepatocellular carcinoma in blacks born and living in an urban environment and to investigate the hepatitis B virus state of these patients.

\section{Subjects and methods}

Case-control study-The case-control study comprised 392 urban but otherwise unselected southern African blacks with histologically proved hepatocellular carcinoma and 392 matched controls. "Urban" blacks were 
defined as those who had been living in an urban environment for at least the past two years. The patients with hepatocellular carcinoma were seen prospectively in the medical and surgical wards of two large general hospitals-Baragwanath Hospital, which is situated in Soweto 12 miles (19 $\mathrm{km}$ ) to the south west of Johannesburg, and Hillbrow Hospital, which is located in central Johannesburg. The controls were matched with the patients with hepatocellular carcinoma for race, sex, age, hospital, ward, and, when possible, tribe. The patients ranged in age from 7 to 87 years (mean 49.3); 330 were male (mean age 50.3 years) and 62 female (mean age $44 \cdot 3$ years), giving a sex ratio of $5 \cdot 3: 1 \cdot 0$. In each case the patients and matched controls were questioned by one of us about their place of birth, where they grew up and attended school, and, in the case of rural born blacks, at what age they came to the city. On the basis of their answers the

TABLE I-Case-control study: comparison between patients with hepatocellular carcinoma and matched controls with respect to urban or rural place of birth

\begin{tabular}{|c|c|c|c|c|c|c|c|}
\hline & \multicolumn{3}{|c|}{ Controls } & \multicolumn{3}{|c|}{$\begin{array}{l}\text { Patients with } \\
\text { hepatocellular carcinoma }\end{array}$} & \multirow[b]{2}{*}{ Significance } \\
\hline & Rural & Urban & Ratio & Rural & Urban & Ratio & \\
\hline $\begin{array}{l}\text { Male patients }(n=330) \\
\text { Female patients }(n=62)\end{array}$ & $\begin{array}{r}176 \\
31\end{array}$ & $\begin{array}{r}154 \\
31\end{array}$ & $\begin{array}{l}1 \cdot 1: 1 \cdot 0 \\
1 \cdot 0: 1 \cdot 0\end{array}$ & $\begin{array}{r}281 \\
43\end{array}$ & $\begin{array}{l}49 \\
19\end{array}$ & $\begin{array}{l}5 \cdot 7: 1 \cdot 0 \\
2 \cdot 3: 1 \cdot 0\end{array}$ & $\begin{array}{l}p<0.0001 \\
p<0.05\end{array}$ \\
\hline Total $(n=392)$ & 207 & 185 & $1 \cdot 1: 1 \cdot 0$ & 324 & 68 & $4 \cdot 8: 1 \cdot 0$ & $\mathrm{p}<0.0001$ \\
\hline
\end{tabular}

TABLE II-Tribal distribution of southern African blacks with hepatocellular carcinoma and matched controls

\begin{tabular}{lcc}
\hline Tribe & $\begin{array}{c}\text { No (\%) of patients } \\
\text { with hepatocellular } \\
\text { carcinoma }\end{array}$ & $\begin{array}{c}\text { No (\%) of } \\
\text { controls }\end{array}$ \\
\hline Zulu & $91(23 \cdot 2)$ & $101(25 \cdot 8)$ \\
Sotho & $70(17 \cdot 9)$ & $100(25 \cdot 5) \star$ \\
Xhosa & $71(18 \cdot 1)$ & $43(11 \cdot 0)^{\star \star}$ \\
Shangaan & $38(9 \cdot 7)$ & $29(7 \cdot 4)$ \\
Tswana & $36(9 \cdot 2)$ & $42(10 \cdot 7)$ \\
Venda & $24(6 \cdot 1)$ & $13(3 \cdot 3)$ \\
Mpedi & $23(5 \cdot 9)$ & $17(4 \cdot 3)$ \\
Swazi & $21(5 \cdot 4)$ & $27(6 \cdot 9)$ \\
Others & $18(4 \cdot 6)$ & $20(5 \cdot 1)$ \\
\hline Total & $392(100 \cdot 0)$ & $392(100 \cdot 0)$ \\
\hline${ }^{\star} \mathrm{p}<0 \cdot 05$. & $\star \star \mathrm{p}<0 \cdot 01$. & \\
\hline
\end{tabular}

patients and controls were classified as urban born or rural born. Without exception the blacks born in rural areas had migrated to the city during late adolescence or adulthood. Those patients with hepatocellular carcinoma who had come to Soweto or Johannesburg for the express purpose of receiving medical attention or had been living in the city for less than two years were excluded from the analysis.

Hepatitis $B$ virus states of urban born blacks-Serological markers of hepatitis $B$ virus infection in 62 of the urban born blacks with hepatocellular carcinoma were compared with those of 62 matched rural born patients with hepatocellular carcinoma and 62 matched urban born subjects admitted to hospital for diseases other than hepatocellular carcinoma. The urban born and rural born patients with hepatocellular carcinoma were matched for race, sex, age, and, when possible, tribe; the urban born patients with hepatocellular carcinoma and the controls were, in addition, matched for hospital and ward. The matched groups each comprised 41 male and 21 female patients with an age range of 7 to 74 years (mean $45 \cdot 2$ ). The tribal distribution was similar in the two groups of patients and controls. Hepatitis B surface antigen (HBsAg) and antibody (anti-HBs) and antibody against hepatitis B core antigen (anti-HBc) were measured by double antibody radioimmunoassay (Ausria II, Ausab, and Corab, respectively; Abbott Laboratories, Chicago).

Statistical analysis was by $\chi^{2}$ and Student's $t$ tests.

\section{Results}

Case-control study-The ratio of rural born to urban born patients with hepatocellular carcinoma differed significantly between the sexes (male patients $5 \cdot 7: 1 \cdot 0$, female patients $2 \cdot 3: 1 \cdot 0 ; \mathrm{p}<0 \cdot 01$ ) (table I). The sex distribution of rural born male and female patients with hepatocellular carcinoma was $6 \cdot 5: 1 \cdot 0$ and of urban born male and female patients $2 \cdot 6: 1 \cdot 0$; this difference was significant $(p<0.01)$. Urban born male patients with hepatocellular carcinoma were significantly younger than rural born male patients with the disease (mean 46.7 (SD 16.3) and 50.9 (14.4) years, respectively; $\mathrm{p}<0.05)$, and the same was true in the female patients $(38.7$ $(\mathrm{SD} 19 \cdot 1)$ and $47.9(14.6)$ years, respectively; $\mathrm{p}<0.05)$. In many cases we could not match the patients with hepatocellular carcinoma and controls by tribe. Nevertheless, aside from more Xhosas and fewer Sothos being represented among the patients with hepatocellular carcinoma than the controls the tribal distribution of the two populations was similar (table II).

Hepatitis B virus state of urban born blacks-Table III shows the hepatitis B virus state of the rural born and urban born patients with hepatocellular carcinoma and matched controls. In brief, evidence of current hepatitis B virus infection (presence of $\mathrm{HBsAg}$ ), past hepatitis $\mathrm{B}$ virus infection (presence of anti-HBc or anti-HBs, or both), total hepatitis B virus markers, and no hepatitis B virus markers occurred equally often in urban born and rural born patients with hepatocellular carcinoma. Urban born patients had markers of current hepatitis B virus infection and total hepatitis B virus markers significantly more often than the controls. The frequency of past hepatitis $B$ virus infection was similar in urban born patients and urban born controls.

TABLE III-Markers of current or past hepatitis $B$ virus infection in urban born black patients with hepatocellular carcinoma in comparison with matched rural born patients and matched controls

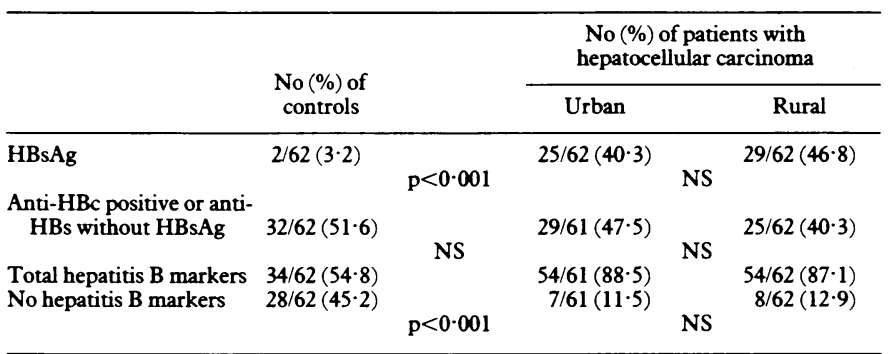

\section{Discussion}

No epidemiological or necropsy analysis of the incidence of hepatocellular carcinoma in southern African blacks has included detailed information on the place of birth and subsequent geographical movements of patients, and the necropsy forms in current use do not include this information. Nor is there at present a local cancer registry of patients with hepatocellular carcinoma. Published incidence data ${ }^{45}$ are based mainly on rural blacks. Even when urban populations have been analysed the samples were composed largely of blacks who had been born in rural districts and had migrated to the cities in late adolescence or adulthood or who had come to the city with the express purpose of seeking medical attention. Consequently no reliable information is available about the incidence of the tumour in blacks born in urban areas. Our case-control study was aimed at providing these data.

Patients with hepatocellular carcinoma included in the investigation were seen prospectively at two large general hospitals and the matched controls were drawn from the same hospitals. With very few exceptions, all black people living in Soweto or Johannesburg who need hospital care are admitted to one or other of these hospitals (until recently there were no private hospitals in Soweto, and even now there are very few private facilities for black patients). By determining the overall ratio of urban born to rural born patients at these two hospitals and comparing it with the ratio among patients with hepatocellular carcinoma it may be possible to draw inferences about the relative frequency of the tumour among urban born and rural born blacks. The ratio of urban born to rural born blacks living in Soweto and Johannesburg is extremely difficult to determine, mainly because, though the population of Soweto is officially just over two million, in reality it is nearer four million.

From our findings we infer that southern African blacks who are born and grow up in an urban environment have an appreciably 
lower frequency of hepatocellular carcinoma than rural born blacks $(p<0.0001)$. An urban-rural difference of this order in the frequency of hepatocellular carcinoma may provide valuable clues about the aetiology and pathogenesis of the tumour. Urban born blacks have recently been shown to have a far lower carriage rate of hepatitis B virus than blacks born in rural areas. ${ }^{239}$ There is already considerable epidemiological and molecular biological evidence that the virus has a pivotal aetiological role in hepatocellular carcinoma. ${ }^{1011}$ Finding that a change in prevalence of chronic hepatitis $B$ virus infection in a population is paralleled by a change in the frequency of hepatocellular carcinoma in that population provides further evidence for this causal association. With the accelerating rate of urbanisation of black people of southern Africa during the past few decades the existing high rate of chronic hepatitis $B$ virus infection in blacks may be expected substantially to decline, even in the absence of a vaccination programme. Our findings suggest that the latter will be followed, after an appropriate interval, by a significant decrease in the incidence of hepatocellular carcinoma.

The hepatitis B virus state of rural born blacks with hepatocellular carcinoma (whether they remain in a rural environment or subsequently move to the cities) has been well documented. ${ }^{72}$ This information, however, has not been available for blacks born in urban areas. Our study has shown that urban born blacks with hepatocellular carcinoma have the same prevalence of current and past infection with hepatitis B virus as matched rural born blacks with this tumour. Thus, though urban born blacks are at a lower risk of developing hepatocellular carcinoma than their rural born counterparts, when they do develop the tumour it is equally likely to be related to hepatitis B virus infection. As expected from previous investigations, ${ }^{912}$ both urban born and rural born blacks with hepatocellular carcinoma had a very much higher rate of current and total hepatitis B virus infection than matched controls $(p<0.001)$. The rate of past exposure to the virus was the same in the urban born patients and urban born controls. This finding too is in keeping with previous studies in rural blacks. ${ }^{8}{ }^{12}$ With a large endemic pool of hepatitis $B$ virus carriers, exposure to the virus is very common and a large proportion of the population would be expected to show serological evidence of past infection. What distinguishes patients with hepatocellular carcinoma from the others is that they become infected in the early months of life and, for reasons which have yet to be clarified, become carriers. With the passage of time some patients may succeed in clearing HBsAg from their serum and becoming anti-HBs positive, but by then hepatitis $B$ virus deoxyribonucleic acid has become integrated into the human genome, setting the stage for subsequent malignant transformation.

Hepatitis B virus vaccines are currently being administered to newly born infants in those parts of the world where chronic hepatitis B virus infection and hepatocellular carcinoma are endemic. Though the immunogenicity of these vaccines and their efficacy in preventing hepatitis B virus infection have been established, many years will inevitably have to elapse before it will be possible to determine whether the vaccination programme will reduce the incidence of hepatocellular carcinoma. In the mean time the observation that a decrease in the hepatitis B virus carrier rate consequent on urbanisation is accompanied by a fall in the frequency of hepatocellular carcinoma gives cause for optimism.

The discrepancy in the frequency of hepatocellular carcinoma between rural born and urban born blacks was far greater in male than in female patients $(5 \cdot 7: 1 \cdot 0 v 2 \cdot 3: 1 \cdot 0)$. Arguably this phenomenon may be explained by a greater propensity of men than women to migrate to the cities. Nevertheless, there is no discrepancy in hepatitis $B$ virus carrier rates between rural born and urban born men and women $(1 \cdot 8: 1 \cdot 0 v 2 \cdot 5: 1 \cdot 0),{ }^{239}$ and the sex ratio of the rural born male and female patients with hepatocellular carcinoma in our analysis $(6 \cdot 5: 1 \cdot 0)$ is not dissimilar from that recorded in rural areas $(5 \cdot 0-6 \cdot 0: 1 \cdot 0){ }^{6}$ Given that chronic hepatitis $B$ virus infection has an equally important aetiological role in both populations, a possible explanation for this difference is that one or more cocarcinogens are present in the rural environment which affect men to a greater extent than women-for instance, a naturally occurring dietary carcinogen, such as aflatoxin, which would affect men more than women because of their greater food intake or because of differences in the metabolic handling of the substance. There is other epidemiological evidence compatible with a role of a cocarcinogen in the aetiology and pathogenesis of hepatocellular carcinoma. Firstly, the tumour is five or six times more common in black men than women, ${ }^{6}$ whereas chronic hepatitis B virus infection is only one and a half times to twice as common in men. ${ }^{239}$ The incidence of hepatocellular carcinoma decreases ${ }^{45}$ and the tumour presents at an older age when blacks born in rural areas become urbanised. ${ }^{12}$ This occurs despite the prevalence of hepatitis B virus infection in the two populations being the same ${ }^{12}$ and suggests that blacks who become urbanised "escape" from a potent rural environmental cocarcinogen.

If rural born blacks who are carriers of hepatitis B virus and either have or will develop hepatocellular carcinoma are more likely, for any reason, to migrate to the cities, this could distort the findings in the present analysis. The prognosis of hepatocellular carcinoma in rural southern African blacks is so grave, however (the mean survival time from the onset of symptoms is only 11 weeks), that patients already having hepatocellular carcinoma, whether related to hepatitis B virus infection or not, would not survive the two years after urbanisation required for inclusion in the study. Because most black carriers of hepatitis $B$ virus are asymptomatic and unaware of their carrier state (facilities for testing for $\mathrm{HBsAg}$ are not available in the rural areas of southern Africa) there is no reason why they should be more likely than non-carriers to migrate to an urban environment.

Why urban born black patients are younger than rural born blacks who later become urbanised remains to be explained. In industrialised countries hepatocellular carcinoma is relatively more common in younger than in older women. ${ }^{13}$ The use of oral contraceptive steroids ${ }^{14}$ and the propensity for the fibrolamellar variant of hepatocellular carcinoma to occur particularly in young women $^{15}$ may be important in this regard. Possibly urban born women are more likely than rural born women who become urbanised to use oral contraceptives, but this remains to be determined, and no formal analysis of oral contraceptive usage was undertaken in this study. Fibrolamellar hepatocellular carcinoma has thus far not been seen in South African blacks. ${ }^{16}$

This work was supported by grants from the Poliomyelitis Research Foundation and the Standard Bank (South Africa).

\section{References}

1 Bersohn I, Macnab GM, Pyzikowska J, Kew MC. The prevalence of hepatitis B (Australia) antigen in southern Africa. $S$ Afr Med $\mathcal{F}$ 1974;48:941-4.

2 Prozesky OW, Szmuness W, Stevens CE, et al. Baseline epidemiological studies for a hepatitis B vaccine trial in Kangwane. S Afr Med f 1983;64:891-3.

3 Botha JF, Ritchie MJJ, Dusheiko GM, Mouton HWK, Kew MC. Hepatitis B virus carrier state in Black children in Ovamboland: role of peri-natal and horizontal infection. Lancet 1984;ii: 1209-12.

4 Dunham L, Bailar JC. World maps of cancer mortality rates and frequency rates. Fournal of the National Cancer Institute 1968:41:155-204.

5 Waterhouse J, Muir C, Powell J. Cancer incidence in five continents. Lyons, France: World Health Organisation, 1977.

6 Prates MD. Cancer and cirrhosis of the liver in the Portuguese east African. Acta; Unio Internationalis Contra Cancrum 1961;17:718-39.
.

Kew MC, Geddes EW. Hepatocellular carcinoma in rural southern African blacks. Medicine (Baltimore) 1982;61:98-108

$8 \mathrm{Kew}$ MC. The possible etiologic role of the hepatitis B virus in hepatocellular carcinoma: evidence from southern Africa. In: Chisari FV, ed. Advances in hepatitis research. New York: Masson, 1984:203-15.

9 DiBisceglie AM, Kew MC, Dusheiko GM, et al. The prevalence of hepatitis B virus infection in black children in Soweto. Br Med f 1986;292:1440-2.

$10 \mathrm{Kew}$ MC. The hepatitis B virus and hepatocellular carcinoma. Semin $L$ iver Dis 1981;1:59-67.

11 Beasley RP, Hwang L-Y. Hepatocellular carcinoma and hepatitis B virus. Semin Liver Dis 1984;4:113-21

12 Kew MC, Rossouw E, Hodkinson J, Paterson A, Dusheiko GM, Whitcutt M. Hepatitis B virus status of southern African blacks with hepatocellular carcinoma: comparison between rural and status of southern African blacks with hep
urban patients. Hepatology 1983;3:65-8.

13 Ihde DC, Sherlock P, Winawer SJ, Fortner JG. Clinical manifestations of hepatoma. Am $\mathcal{~}$ Med 1974;56:83-91.

14 Shar SR, Kew MC. Oral contraceptives and hepatocellular carcinoma. Cancer 1982;49:407-10

14 Shar SR, Kew MC. Oral contraceptives and hepatocellular carcinoma. Cancer 1982;49:407-10. araig JR, Peters RL, Edmondson HA, Omata M. Fibrolamellar carcinoma of the liver: a tumor of
adolescence and young adults with distinctive clinico-pathologic features. Cancer 1980;46:

16 Van Tonder S, Kew MC, Hodkinson J, Metz J, Fernandes-Costa F. Serum vitamin B12 binders in southern African blacks with hepatocellular carcinoma. Cancer 1985;56:789-92.

(Accepted 9 September 1986) 